\title{
THE ROLE OF UNIVERSITIES IN CONSOLIDATING INTELLECTUAL CAPITAL AND GENERATING NEW KNOWLEDGE FOR A SUSTAINABLE BIO-ECONOMY
}

\author{
Adriana Tiron-Tudor ${ }^{1 *}$, Cristina Silvia Nistor ${ }^{2}$ \\ and Cristina Alexandrina Ştefănescu ${ }^{3}$ \\ 1), 2), 3) Babeş-Bolyai University, Cluj-Napoca, Romania
}

Please cite this article as:

Tiron-Tudor, A., Nistor, C.S. and Ştefănescu, C.A., 2018.

The Role of Universities in Consolidating Intelectual

Capital and Generating New Knowledge for a Sustainable

Bio-Economy. Amfiteatru Economic, 20(49), pp. 599-615.

Article History

Received: 30 March 2018

Revised: 20 May 2018

Accepted: 20 June 2018

DOI: $10.24818 / \mathrm{EA} / 2018 / 49 / 599$

\begin{abstract}
This study focuses on the wide debated concept of bio-economy, underlying its evolution and connection with universities' goal, from the intellectual capital (IC) perspective. It's aim is to highlight the mutual influence of IC disclosures and knowledge management in its ability to foster the development of the bio economic environment. Thus, this paper covers a significant gap by approaching the universities' IC disclosure and bio-economy evolution. It also enriches the literature by underpinning the proposed model on the macroeconomics theories (public interest theory, stakeholders or agency theory). These theories supports the need to enhance transparency and accountability through greater disclosure levels.

The empirical research performed by combining the qualitative analysis performed for developing the IC disclosure index with the quantitative techniques enable us to develop an econometric model on the Romanian public universities. It is aimed to express their role in the IC as a mean of achieving a sustainable economy.

The study' results reveal that there is a strong connection between the IC disclosure and bio-economy, knowing that public universities are research clusters for innovative and durable economy environment. Moreover, based on the Romanian public universities' position, we identified and discussed about the explanatory factors influencing the IC disclosures, which can help or stimulate the association between the public and private interest, having bio-economy as a focus point.
\end{abstract}

Keywords: bio-economics, intellectual capital, universities.

JEL Classification: Q57, O34, I25.

* Corresponding author, Adriana Tiron-Tudor - adriana.tiron@econ.ubbcluj.ro 


\section{Introduction}

Considering the critical role that intellectual capital (IC) plays in a contemporary organization (Low, Samkin and Li, 2015), the bio-economy evolution is connected with knowledge-based society through universities. The new entrepreneurial feature of universities, sustain the idea that disclosure of intangibles are necessary for making universities more flexible, competitive and connected with the real societies evolution (Sanchez and Elena, 2006). In this context, the development of bio-economy as well as increased interest in IC and knowledge management, makes our study to be firmly determined to fulfill the scientific literature gaps regarding the universities' IC disclosure and bio-economy evolution.

Based on this approach, the primary objective of this paper is to investigate the socioeconomic role of universities, reflecting on the importance of IC disclosure and knowledge management in its ability to foster the development of the economic environment (e.g. bioeconomy sphere). This topic is discuss also by other authors (Low, Samkin and Li, 2015; Sangiorgi and Siboni, 2017) but this paper makes an original approach of the Romanian public universities' IC disclosure, using content analysis (Boubacher, Lakhal and Nekhili, 2011; Gallego-Alvarez, Rodriguez-Dominguez and Garcia-Sanchez, 2011) with references to the information and the content provided by their websites from the IC perspective. The IC checklist was based on Sanchez et al. (2006), Schneider and Samkin (2008), Yi and Davey (2010) and Low et al. (2015) research and adapted to the Romanian specific framework. The bidirectional analyses of connection between IC disclosure and universities capacities to sustain the bio-economy environments are the main results, which have a high originality degree also for international and national specific literature.

From the empirical perspective, we successfully combined the qualitative analysis performed for developing the IC disclosure index with the quantitative techniques. In this respect, a regression model on the Romanian public universities was developed, aimed to express their role in the IC as a mean of achieving a sustainable economy.

In the light of specific economic theories (public interest theory, stakeholders or agency theory), the validation of the obtained results is a point of reference in approaching the university-bioeconomy connection in the next period. The study addresses a broad range of users: theoreticians who wish to understand the real link between universities and bio-economy, IC and his influence on research and society's needs, the evolution of the know-based society concept; practitioners who have the chance to familiarize themselves with the implications of the topic analyzed through the eyes of a specialist; professional bodies/legislators/societies as a whole, who will have a concrete and precise basis for future analysis oriented to the acceptance and inclusion of these new approaches in regulations or specific actions.

The remainder of this paper proceeds as follows. Firstly, the theoretical background for the bioeconomy evolution and its connection with universities' scope, from the IC perspective, is connected with the IC university disclosure framework based on specific literature and the Romanian educational environment's characteristics. Also, various theories (public interest theory, stakeholders or agency theory), macroeconomic background for IC disclosure approach are part of section 1. Section 2 is dedicated to the methodology framework, focused firstly on presenting the research design (methods used, sampling, variable measurement, disclosure index development), followed by an econometric analysis performed for developing the proposed model. The results and discussion points the main findings of our study in section 3 . The final part of the paper regards conclusions, limits and further developments. 


\section{Literature review}

\subsection{Bio-economy and universities' activities}

Bio-economy in general and a sustainable one, in particular, became overtime an essential topic at international, regional and national level. The concept is "based on parallel knowledge and application of social, economic and biophysical principles and emphasized the importance of an understanding the reciprocal influence of this principles" (Giampietro and Passtore, 1999). Bio-economy has been identified as a tool to address a wide range of societal challenges in the next decades: food security, climate change, sustainable resource management, private companies' competitiveness, job creation and the high dependence on non-renewable resources (McCormick and Kautto, 2013; Staffas, Gustavsson and McCormick, 2013).

Until now, many states have developed strategies and policies related to different biotechnology and bio-based industries and products, but more and more countries are developing strategies that collect all these separate topics under the conceptual umbrella of the bio-economy (Staffas, Gustavsson and McCormick, 2013).

Some national strategies also consider the capacity to generate know-how in this area and the promotion of the public and private collaboration, as well as the contribution to the economic growth by creating new jobs and fostering investments (Lainez et al., 2018).

At the EU level, bio-economy is a priority area of research, development and innovation policy. Through all these features, bio-economy is an intrinsic and vital component of the knowledge economy. Bio-economy's sub-sectors have a strong innovation potential by using a wide range of sciences (life sciences, agronomy, ecology, food and social sciences) (McCormick and Kautto, 2013).

The development of a knowledge economy along with the growing recognition of universities as the drivers of progress (Dragoș et al., 2014) due to their creative potential available, has led to increasing awareness of their role as producers of knowledge and innovation for a sustainable bio-economy. Nowadays, the fundamental task of universities is to generate knowledge through education, development of research and interaction (Deaconu and Nistor, 2017) with the local economic and social environment, and to transfer it to the industry (Urdari, Farcas and Tiron-Tudor, 2017). In this way, universities, alongside other local and regional players contribute to regional economic development (Dabija et al., 2017).

A great opportunity for universities is to seek to transfer technology to the private sector, and therefore capture the benefits of commercialization of their innovation and intellectual property rights through many different mechanisms. For universities, technology transfer by way of licensing out can successfully and efficiently bring their implication through to the marketplace (Krauss and Kuttenkeuler, 2018). For them, intellectual property is the currency of today's knowledge economy and tech transfer, mainly in the form of patents.

Clustering and innovation within bio-economy are augmented further by desirable criteria such as containing high-quality universities. Collaboration between institutions and industry also increases innovation output. Beyond this, the quality of those collaborations is essential to successfully benefit from these criteria (Satler and Martin, 2001).

The European Union has recognized universities as an essential resource for innovation and seeks to support the innovative activities. Actions funded can be the risk assessment, design 
or market studies, or intellectual property exploration (Krauss and Kuttenkeuler, 2018). It is known that academic research on economics is mainly conducted by universities (Dragos et al., 2014). Many universities operate a technology transfer office (TTO) to improve the university and its commercial ties with industry, as a vehicle to support the creation of spinoff companies (Hague and Oakley, 2000). The universities are engaged in policy and national or regional strategy development. Moreover, the strategies engage universities, more efficiently, in development and innovation processes (Urdari, Farcas and Tiron-Tudor, 2017).

Romania has a high potential to develop a bio-based economy because it is a country endowed with a large variety of natural resources (forests, natural gas, fertile agricultural lands $-7.5 \%$ of utilized agricultural area in EU - (EC, 2012).The bi-directional connection between universities, knowledge creators and the economic environment, knowledge user and resource generator, can be synthesized from Romanian bio-economy development in ways like transfer of knowledge to companies or functional experimental research for products, technologies, methods, systems or services, as well as significant improvement in the areas of smart specialization (Romanian Goverment, 2014).

Bioeconomics is heavily reliant on academic research. A strong academic environment can guarantee the existence and management of the resources needed for complex, laborious and expensive research, development and implementation. Starting from these arguments transposed into the context of Romania, the article supports the idea that the CI-universitiesbioeconomy is the key to progress in the field, which without sustained academic research cannot be successful, and some successful practices are presented.

\subsection{Intellectual capital concept - development and disclosure index}

The bio-economic development should achieve the highest knowledge levels based on the university sector defined as a knowledge-intensive industry (Fazlagic, 2005). The connection between universities and the new concepts' development (e.g. bio-economies, sustainability) would assure that knowledge and intangible assets become the primary source of competitive advantage (Ramirez, Tejada and Manzaneque, 2016).

IC can be defined as "the collection of intangibles which allows an organization to transfer a collection of material, financial and human resources into a system capable of creating value for the stakeholders" (EC, 2006). The public universities are an ideal epicenter for the request of the IC concept, because they make rigorous use of intangible assets such as human resources, skills, abilities and knowledge (Manes Rossi, Citro and Bisogno, 2016). Moreover, regulators and scholars have developed guidelines and frameworks to support the correct identification of the IC components and stimulate the diffusion of common practices of managing and reporting IC within universities (Ramirez, Tejada and Manzaneque, 2016; Sangiorgi and Siboni, 2017).

In the current "universal knowledge network" (van Weenen, 2000), with a performance-oriented culture (Dumay, 2016), the high performance of IC disclosure can provide and motivate the improvement of human capital and the engendering of new knowledge for the achievement of a sustainable bio-economy. The IC disclosure, defined as the pillar of public accountability and sustainability (Low, Samkin and Li, 2015), would have a favorable impact among public stakeholders (Olivieira, Rodrigues and Craig, 2013) by supporting the management control over the resources, needs and opportunities for developing own human capital, by increase the attractiveness of individuals with higher skills and experiences for a public interest alliances (Low, 
Samkin and Li, 2015) (e.g. private-public partnership, common research objectives), and it would support modern approach to global essential development topics (e.g. sustainable development, bio-economy) as the most significant challenge to universities in the twenty-first century.

The IC disclosure structure used in this paper is based on the components presented in Table no. 1 including also the particularities of the Romanian higher education IC disclosure needs. The universities' IC components are usually grouped into the following three main categories (Sanchez, Elena and Castrillo, 2006; Schneider and Samkin, 2008; Yi and Davey, 2010; Low, Samkin and Li, 2015; Ramirez, Tejada and Manzaneque, 2016; Secundo, Beer and Passiante, 2017) presented in table no. 1.

Table no. 1: IC categories and components

\begin{tabular}{|c|c|c|}
\hline & IC components & Descriptions \\
\hline \multirow{8}{*}{ 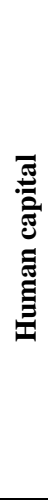 } & $\begin{array}{l}\text { Work-related knowledge/ } \\
\text { know-how }\end{array}$ & $\begin{array}{l}\text { Individual competencies of researchers, knowledge or } \\
\text { skill obtained from the job or training }\end{array}$ \\
\hline & Employees & $\begin{array}{l}\text { Staff, researchers, lecturers, PhD students, and } \\
\text { administrative personnel }\end{array}$ \\
\hline & $\begin{array}{l}\text { Mobility programs } \\
\text { for employees }\end{array}$ & $\begin{array}{l}\text { Mobility programs for researchers and professors and } \\
\text { international programs (Erasmus) }\end{array}$ \\
\hline & $\begin{array}{l}\text { Employee's experience } \\
\text { in profession }\end{array}$ & $\begin{array}{l}\text { Employees' international or national experiences in their } \\
\text { profession }\end{array}$ \\
\hline & Employee qualification & Related issues to employees' qualifications \\
\hline & Employee compensation/benefit & Welfare or other benefits for employees and PhD students \\
\hline & Training program & $\begin{array}{l}\text { Education or training programs for employees provided } \\
\text { by a university }\end{array}$ \\
\hline & $\begin{array}{l}\text { Internationalization of teaching } \\
\text { staff }\end{array}$ & Visiting professor or researcher at university \\
\hline \multirow{7}{*}{ 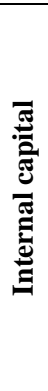 } & Patents Right & Patents held by sample university \\
\hline & Publications & $\begin{array}{l}\text { Journals, books, e-journals, chapters developed by } \\
\text { researchers and held by sample university }\end{array}$ \\
\hline & University Culture & $\begin{array}{l}\text { Comprising the vision, attitudes, experiences, beliefs, and } \\
\text { values of a university }\end{array}$ \\
\hline & Management outline & Strategy, mission and objectives \\
\hline & $\begin{array}{l}\text { Infrastructural/networking } \\
\text { connections }\end{array}$ & $\begin{array}{l}\text { University's infrastructural development/ICT } \\
\text { technologies }\end{array}$ \\
\hline & National Research projects & Research projects conducted by a university \\
\hline & $\begin{array}{l}\text { European and International } \\
\text { Research projects }\end{array}$ & Research projects conducted by a university \\
\hline \multirow{7}{*}{ 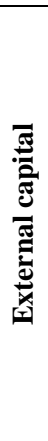 } & Brand & Brands associated with the university \\
\hline & Quality standards & Teaching or learning quality \\
\hline & Entrepreneurial University & $\begin{array}{l}\text { All the activities and collaboration with other groups } \\
\text { (firms, nonprofit organizations, public authorities, local } \\
\text { government, and society as a whole) }\end{array}$ \\
\hline & $\begin{array}{l}\text { Research consortia } \\
\text { and technological clusters }\end{array}$ & Related issues to research consortia, technological clusters \\
\hline & Student database & Database of all students \\
\hline & Student satisfaction & $\begin{array}{l}\text { Students and their satisfaction with the } \\
\text { learning/researching process }\end{array}$ \\
\hline & $\begin{array}{l}\text { International programs } \\
\text { for students' mobility }\end{array}$ & $\begin{array}{l}\text { Mobility programs for students and international } \\
\text { programs (e.g., Erasmus, CEEPUS) }\end{array}$ \\
\hline
\end{tabular}

Source: Adapted from Sanchez, Elena and Castrillo, 2006; Schneider and Samkin, 2008; Yi and Davey, 2010; Low, Samkin and Li, 2015 


\subsection{Theories explaining the dependence between bio-economy and intellectual capital}

Macroeconomic theories motivate this approach. These succeed to place the influence of the IC disclosure through the public interest theory, stakeholders or agency theory.

The first one presumes that public servants are motivated by a desire to maximize society's welfare, which provides theoretical justifications for its regulation. Through a requested disclosure of the IC, the public sphere is motivated by societal interests and intervenes in the market to improve social outcomes (Ramirez, Tejada and Manzaneque, 2016).

The stakeholders' theory suggests that public entities voluntary disclosure can improve their reputation (an essential resource for them) by negotiating and influencing stakeholders (Oliveira, Rodrigues and Craig, 2013). Because relationships with stakeholders request greater transparency and accountability to improve decision-making process (Sangiorgi and Siboni, 2017) the ability of a public university to establish and maintain such relationships can affect its fundamental sources of reputation. By providing comprehensive disclosure to significant stakeholders, public entities satisfy both their obligation and responsibility to the varied society (Donaldson and Preston, 1995).

The agency theory recognizes the need to develop monitoring tools and improved accounting instruments (Oliveira, Rodrigues and Craig, 2013).) to make efficient decisions by having information about foremost value creators in the long term. IC disclosure can become a meaningful way to reduce the asymmetries of information between the parties (principal/agent), knowing that universities are considered a set of socio-economic agents. However, from the perspective of agency theory an appropriate disclosure will offer information useful for the decision-making process.

\section{Methodological Framework}

\subsection{Research design}

For achieving the paper's aim to highlight the critical value of bio-economy as a component of the knowledge economy we followed the main research methodologies and tools used in prior studies conducted on a similar topic (Cuozzo et al., 2017), based on a combination of quantitative and qualitative approaches. Thus, we developed a model expressing the role of universities' IC as a mean for achieving a sustainable economy, based on the disclosure index created (detailed in the prior section) and its determinants.

For our study, 53 universities of category A and B, respectively with research valences, were included in the classification OG 5262/2011, which according to art. 193 of the Education Law no.1 / 2011, evaluates universities and programs studies in 3 categories: advanced research, B education and scientific research and $\mathrm{C}$ education.

The content analysis based on making valid inferences from universities' annual reports and websites data according to their context (Krippendorf, 2013) was carried out in the first stage of our study. This type of qualitative analysis was often used in prior studies (Cuozzo et al., 2017) and it proved to be an empirically valid research method in this field (Low, Samkin and Li, 2015; Dumay and Guthrie, 2017), despite its subjectivity and lack of reliability (Dumay and Cai, 2015). 
Aiming to add value to the research literature, we applied a "meaning oriented" content analysis for a great understanding of the specific inferences of the IC. Basing on this interpretative approach, we focused on the quality and richness of texts' interpretation during the information selection process. Moreover, we tried to comply with certain technical requirements to increase the effectiveness of the content analysis performed. Thus, we clearly defined the items of analysis and systematically captured the data (Krippendorff, 2013). Likewise, to ensure its validity and reliability, we used a coding instrument with wellspecified items of analysis, and we appealed to the second research-coder to minimize any discrepancies, thus increasing the results' trustworthiness.

The second stage of research involved a quantitative approach based on the IC disclosure index developed and the statistical analysis performed to develop a model revealing the universities' role in preparing and improving the IC as a basis for significant social transformations supported by bio-economy. Prior literature provides a wide range of models used for testing the extent and type of influence of various factors upon the IC disclosure at a company level (Methora, V., Methora, A.K. and Chauhan, 2017). In the public sector, there are studies analyzing the determinants of various types of disclosure, such as financial (Gordon and Fischer, 2008), accountability (Ismail and Bakar, 2011), performance or online information (Gallego-Alvarez, Rodriguez-Dominguez and Garcia-Sanchez, 2011; Bisogno, Citro and Tommasetti, 2014), but there is a lack of empirical results on the IC disclosure.

To ensure significance of the proposed model we performed both "enter" and "stepwise" methods of the linear regression, as well as the analysis of variance using ANOVA test, which helped us measuring the strength of the relationship established. The model has also been tested for robustness through multicollinearity (Variance Influence Factor Test) and heteroscedasticity (Boubaker, Lakhal and Nekhili, 2011; Bisogno, Citro and Tommasetti, 2014).

\subsection{Disclosure index development}

The disclosure index, as a qualitative-based instrument designed to provide a score of the transparency level in a specific context was often used by prior researchers to study the voluntary disclosure of IC in annual reports (Schneider and Samkin, 2008). In this study, we based on a theoretical framework detailed in the prior section (An, Davey and Eggleton, 2011;Sanchez, Elena and Castrillo, 2009; Schneider and Samkin, 2008; Yi and Davey, 2010; Low, Samkin and $\mathrm{Li}, 2015)$ and adapted according to the specific features of the Romanian university environment and data sources analyzed. Thus, we developed an un-weighted disclosure index, all data gathered within it being appreciated as equally important to all university stakeholders (Low, Samkin and $\mathrm{Li}, 2015$ ).

Finally, the IC disclosure index developed as presented above will be used in the next stage of our empirical analysis by appealing to statistical tools (linear regression) to identify specific explanatory factors influencing the level of their IC disclosure provided through the annual reports and the websites (Bisogno et al., 2014; Ismail and Bakar, 2011; Gallego-Alvarez, Rodriguez-Dominguez and Garcia-Sanchez, 2011).

\subsection{Sample selection and variable measurement}

To fulfill the research objective, we focused on a sample of Romanian public universities, based on the recent evidence revealing that national educational environment experienced a noticeable trend of internationalization. It was mainly the outcome of the inclusion in the Bologna process (Dumitru et al., 2014), which also provided the premises to align to the 
advanced standards of more developed European higher education institutions. Additionally, the public sector was always seen as an ideal framework for the application of the ideas related to IC theory ((Serrano-Cinca, Mar Molinero and Bossi Queiroz, 2003).

In this context, within this internationalization process that the national educational system has gone through, the IC had a particular role that raised, even more, our interested in research in this field. Consequently, the study sample includes 53 Romanian public universities from the top rank offered by the Romanian Government Order no. 5262/2011 and done following the national education law, which has three-tier structure, namely: (1) Rank A: Universities of advanced research and education; (2) Rank B: Universities of education and scientific research or universities of education and artistic creation; (3) Rank C: Universities focused on education.

For performing the empirical analysis, the potential determinants of the IC disclosure level were mainly selected according to prior studies (that are presented in the next paragraphs) within universities on a similar topic and enriched with new factors appropriate to our research objective. A summary of the variables considered in this research comprising their definition, proxies and expected influences is presented in table no. 2 followed by arguments to justify their inclusion in our empirical analysis.

Table no. 2: Variables description

\begin{tabular}{|c|c|l|c|}
\hline Variable & Acronym & \multicolumn{1}{|c|}{ Proxy } & Sign \\
\hline Size & SIZE & Number of students & + \\
\hline Age & AGE & Number of years since the foundation year & $+/-$ \\
\hline Complexity & COMP & Number of faculties & + \\
\hline Quality & QUAL & $\begin{array}{l}\text { Category of university: (A) advanced research and education; } \\
\text { (B) education and scientific research/education and artistic } \\
\text { creation (C) education }\end{array}$ & + \\
\hline Internationality & INTER & Number of international students & + \\
\hline Sustainability & SUST & $\begin{array}{l}\text { Sustainability issues engagement (internal policy, research } \\
\text { projects) }\end{array}$ & + \\
\hline Bio economy & BIOEC & $\begin{array}{l}\text { Bio-economics issues engagement (master studies, research } \\
\text { projects, conferences) }\end{array}$ & + \\
\hline Type & TYPE & $\begin{array}{l}\text { Universities profile (agricultural, technical, medical, military, } \\
\text { arts, multiple areas) }\end{array}$ & + \\
\hline
\end{tabular}

Source: Authors' projection

The arguments to justify their inclusion in our empirical analysis are:

- Size - Organizational size has been one of the most used variables to explain the level of information disclosure in both private and public sectors. Since the last one is subject to the higher demand for accountability by a wide range of stakeholders Serrano-Cinca, Mar Molinero and Bossi Queiroz, 2003), larger public institutions proved to be more prone to face transparency needs by disclosing information. Prior studies focused on private sector, usually used market capitalization, sales and total assets to appraise corporate size, but in the public sector, the first two determinants are not relevant. In case of universities, an appropriate measurement of their size might be either the gross assets (Gordon and Fischer, 2008) or the number of students (Ismail and Bakar, 2011, Gallego-Alvarez, Rodriguez-Dominguez and Garcia-Sanchez, 2011), the latter being used in our study, too. According to their results, the extent of disclosure is positively and significantly associated with the universities' size. 
- Age - Incipient studies on determinants of transparency level stated that age is a factor of direct and positive influence, even in the educational field, where "established universities tended to have better quality disclosure than new universities" (Banks, Fisher and Nelson, 1997). As regards educational environment, empirical evidence is still uncertain, either providing a positive influence of the university's age over the disclosure level (Ismail and Bakar, 2011;) or any significant relationship (Ismail and Bakar, 2011; Gallego-Alvarez, Rodriguez-Dominguez and Garcia-Sanchez, 2011; Bisogno, Citro and Tommasetti, 2014).

- Complexity - The complexity of a university, reflected by the number of faculties, is another factor that influences the degree of information disclosed, the most complex ones having a greater tendency to disclosure and a real potential content to be revealed. According to previous empirical results, the positive association between the complexity of a university and the transparency level found (Bisogno, Citro and Tommasetti, 2014) was not always significant (Gallego-Alvarez, Rodriguez-Dominguez and Garcia-Sanchez, 2011. It is especially the case of online disclosures, where the main website may lose its importance in large universities, in favor of their faculties' websites (Gallego-Alvarez, RodriguezDominguez and Garcia-Sanchez, 2011).

- Quality - In the last decades, there were intense debates about whether universities can encompass multiple missions such as research, teaching, and additionally, economic development (Leydesdorff and Meyer, 2003). Basing on this background, we appreciated the category of a university as a potential quality factor able to positively influence the level of disclosure. Thus, universities ranked in the best category (advanced research and education universities) will disclose more information to maintain their position and to promote them internationally (Gallego-Alvarez, Rodriguez-Dominguez and Garcia-Sanchez, 2011) compared with universities of education and scientific research and those focused only on education.

- Internationality - Currently, the importance of internationality within universities plays a major role in the recent global, competitive environment that challenged education worldwide. The need for cross-border education has led to the implementation of various exchanged programs (e.g. ERASMUS, CEEPUS) materialized in recruiting the most capable students and researchers to gain a competitive advantage. This new kind of competition has spurred universities in disclosing more information about their education and research activities (Ramírez, Tejada and Manzaneque, 2016). According to prior empirical evidenced a positive relationship between university internationality (number of international students) and the level of disclosure was found (Gallego-Alvarez, Rodriguez-Dominguez and GarciaSanchez, 2011).

- Sustainability - In the last decades, we have witnessed at the development of the sustainability concept encompassing the development and creation of an organisation's longterm value basing on innovation as well as intellectual and relation capital. In this context, public institutions have increasingly embraced the sustainable development discourse (Dabija et al., 2017) thus becoming dynamically involved in developing public policies that encourage social responsibility and accountability. According to prior evidence, more socially responsible universities have a higher web-disclosure index (Bisogno et al., 2014), which led us to the assumption that sustainability is also a potential explanatory factor able to influence the level of the IC disclosure positively.

- Bioeconomy - Since bio-economy is mainstreamed as a global sustainability concept, we decided to consider it as well into our analysis as a potential determinant of the IC disclosure, even though it was not tested before in prior studies conducted on the same topic. 
The main argument in this respect is the fact that prestigious universities with renowned researchers carrying out high quality biomedical and biotechnology research, as well as appropriate collaboration and knowledge transfer into the business environment play an important role into the bio-economies' success (EC 2012). In this context, it is essential for the bio-economy to have an appropriate workforce keeping up-to-date with the new knowledge and techniques, which can be ensured by the existence of multidisciplinary education and proper international training and effective lifelong learning within universities (EC, 2010).

- Type - The type of universities was previously analysed as an explanatory factor of the degree of transparency through their public or private funding. In this regard, public universities have to cope with higher political costs due to the wide range of constituents to whom they are responsible. Thus they are expected to make extensive disclosures consistent with their multifaceted stewardship roles (Gallego-Alvarez, Rodriguez-Dominguez and Garcia-Sanchez, 2011). Because our sample consists only of public universities, we decided to use a different criterion for classifying universities, namely their profile (e.g. technical, medical, agricultural). This typology was only tangential used before by Gallego-Alvarez, Rodriguez-Dominguez and Garcia-Sanchez (2011) who proven that universities with a strong presence of technical degree used their websites more intensely for disclosing information.

\section{Results and discussions}

Correlation analysis using Pearson coefficient provides information upon the direction and significance of influences between the IC disclosure index (independent variable) and its potential determinants (dependent variables). The values of Pearson coefficient among all considered variables, as well as their level of significance are detailed in table no. 3 .

Table no. 3: The correlation matrix between variables

\begin{tabular}{|c|c|c|c|l|l|l|l|l|l|l|}
\hline \multicolumn{2}{|c|}{ Correlations } & ICID & SIZE & AGE & COMP & QUAL & INTER & SUST & BIOEC & TYPE \\
\hline \multirow{3}{*}{ ICDI } & Pearson Correlation & 1 & $.774^{* *}$ & $.302^{*}$ & $.644^{* *}$ & $.569^{* *}$ & $.738^{* *}$ & $.786^{* *}$ & $.666^{* *}$ & $.579^{* *}$ \\
\cline { 2 - 10 } & Sig. (2-tailed) & & .000 & .028 & .000 & .000 & .000 & .000 & .000 & .000 \\
\cline { 2 - 10 } & $\mathbf{N}$ & 53 & 53 & 53 & 53 & 53 & 53 & 53 & 53 & 53 \\
\hline \multicolumn{6}{|c|}{ **. significant at the 0.01 level (2-tailed) / *. significant at the 0.05 level (2-tailed). } \\
\hline
\end{tabular}

Source: Calculations made by authors using SPSS software

By analyzing the values of Pearson's coefficient we reached to the conclusion that all variable tested are associated with the IC disclosure index, thus being possible explanatory factors of university's role in a knowledge society recently marked by challenging endeavors. Thus, universities' size and engagement in sustainability issues proved to have the strongest positive influences of all explanatory factors testes, with a high probability significance of 99\% (Sig.<0.01) and the highest intensity (0.774, respectively 0.786 ). Other positive associations with the same probability, but lower intensity were found in case of university's complexity and internationality, while their age had a lower influence and less significant.

Afterwards, searching for an answer regarding the role of universities in preparing and improving the IC as a basis for significant social transformations supported by bio-economy, we appreciated as the best alternative to developing a model expressing all significant influences of determinants over the level of IC information disclosed by sampled universities. 
In this respect, we used multiple regression as the method of analysis and Ordinary Least Squares $(O L S)$ as the method of estimation. For developing our model, we start with the general economic model:

$\mathrm{Y}=\alpha+\beta_{\mathrm{i}} * \mathrm{~F}_{\mathrm{Xit}}+\mathrm{e}_{\mathrm{it}}$

where:

$\mathrm{Y}$ - the dependent variable (IC disclosure index in our case);

$\alpha \quad$ - constant;

$\beta_{\mathrm{i}} \quad$ - the coefficient of the explanatory variable;

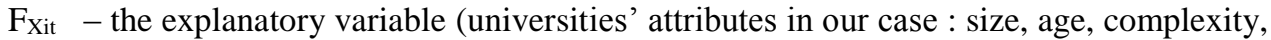
quality, internationalisation, susteinability, bioeconomy and type);

$\mathrm{e}_{\mathrm{it}} \quad$ the error (assumed to have zero mean and to be independent across time period).

Accordingly, we first used the linear regression by applying the enter method and, thus, we identified those independent determinants that proved to explain better the influences over the level of IC disclosure. Unfortunately, the results achieved could not allow us to develop a reliable and robust model comprising all explanatory factors, because even though the IC disclosure index is correlated with most determinants considered, only three of them proved to be significant for explaining the influences identified. Thus, to develop a model comprising all determinants that better explain the influences over IC disclosure level, we had to make use of the stepwise method that helped us to select just those independent variables that were significant, as it can be seen in table no. 4 .

Table no. 4: Regression analysis using stepwise method for IC disclosure

\begin{tabular}{|c|c|c|c|c|c|c|c|}
\hline \multirow[b]{2}{*}{ Model } & \multicolumn{2}{|c|}{ Unstandard Coeff. } & \multicolumn{2}{|c|}{ StandardCoeff. } & \multirow[b]{2}{*}{ Sig. } & \multicolumn{2}{|c|}{ Collinearity } \\
\hline & B & Std. Err & Beta & $\mathbf{t}$ & & Tolerance & VIF \\
\hline (Constant) & 17.164 & 1.584 & & 10.835 & .000 & & \\
\hline SUST & 1.076 & .432 & .259 & 2.487 & $.016^{* * *}$ & .372 & 2.687 \\
\hline SIZE & .000 & .000 & .392 & 4.567 & $.000^{*}$ & .548 & 1.826 \\
\hline QUAL & 1.313 & .396 & .257 & 3.312 & $\left..002^{*}\right)$ & .671 & 1.490 \\
\hline TYPE & .745 & .239 & .265 & 3.117 & $.003^{*}$ & .559 & 1.790 \\
\hline \multirow{2}{*}{\multicolumn{3}{|c|}{$\begin{array}{l}\text { F value: } 49.993 \\
\text { significance: } .000\end{array}$}} & \multicolumn{5}{|c|}{$\begin{array}{c}\text { R Square: .806 } \\
\text { Adjusted R Square: .790 }\end{array}$} \\
\hline & & int for $p-1$ & & ignifica & $r p$-val & 0.05 & \\
\hline
\end{tabular}

Source: calculations made by authors using SPSS software

In conclusion, our model comprises just those independent variables that proved to explain better the influences over the IC disclosure index in approximately $79 \%$ of cases with a probability of $95 \%$.

$\operatorname{ICID}=\alpha+\beta_{1}(\mathrm{SIZE})+\beta_{2}(\mathrm{QUAL})+\beta_{3}(\mathrm{TYPE})+\beta_{4}(\mathrm{SUST})+\mathrm{e}_{\mathrm{i}}$

These results are confirmed by the $\mathrm{R}$ square coefficient value and the analysis of variance performed using ANOVA test, which expresses the strength of each relationship established, the size of the university having the strongest influence, followed by its quality and profile.

Besides the significance of the model, we also tested its robustness. Accordingly, the results confirm that no collinearity exists between the independent variables, all the VIF values being acceptable (the highest one is 2.687 in case of the variable sustainability), thus discharging 
multicollinearity problems since the threshold value is about 10 . Moreover, heteroscedasticity tests were performed (White's and Breusch-Pagan's) and yielded negative results (Boubaker, Lakhal and Nekhili, 2011; Bisogno, Citro and Tommasetti, 2014)

The results reached are consistent with the prior empirical evidence and the theories underlying the proposed model. Thus, the IC disclosures can be firstly perceived both as an essential tool able to reduce the information asymmetry and the potential conflicts of interest as the agency theory states. Moreover, it is a prerequisite of desired public outcomes consistent to societal needs sustained by public interest theory (Gallego-Alvarez, RodriguezDominguez and Garcia-Sanchez, 2011).

Besides, according to the stakeholder theory, larger universities tend to be more transparent to satisfy the information needs of the wide variety of interested stakeholders (taxpayers, students, research centres, governments). These demand greater transparency especially regarding the intellectual capital, resources, research activities' results and educational performances of the universities (Secundo, Beer and Passiante 2016; Sangiorgi and Siboni, 2017). Thus, the expected positive influence of the universities' size on the IC disclosure index confirmed by our model reveals that larger universities have a higher interest in disclosing IC information to enhance the external environment confidence. These results are in line with prior evidence on the same research topic (Gallego-Alvarez, RodriguezDominguez and Garcia-Sanchez, 2011).

Since the quality of education is of major importance when it comes to growth, innovation potential and competitiveness, universities are required to participate in providing knowledge and competence for the growth of a bio-based economy. This demand can be adequately met by advanced research and education universities, which in fact have a significant impact on the IC disclosure as our model reveals.

The universities responded to the new domain of bio-economy at all three levels (education, research and transfer of technologies). At educational level, a significant number of universities introduced a new line of studies at bachelor level, new master programs and $\mathrm{PhD}$ studies focused on bio-economy or bio-economy mixed with another field. The new educational offer in bioeconomy is interdisciplinary and looks at the entire bio-based value chain and networks. Students examine the ecological, social, and economic dimensions of the bio-economy on a micro and macro-level. New research groups focused on bio-economy catalyze researchers and become visible through their conferences, workshops and publications.

An in-depth analysis of universities' profile provides additional evidence consistent with the prior literature (Gallego-Alvarez, Rodriguez-Dominguez and Garcia-Sanchez, 2011) revealing that those universities from the technical, medical and agricultural field are more transparent.

We can exemplify through: specific studies lines like Bio-economy management in the context of sustainable development at University Danubius Galati (Danubius University, 2018), conferences concerning bio-economy development priorities in Botosani Suceava zone (Ministry of Research and Innovation, 2016), clusters with activities relates to bio-economy or national funding through UEFISCDI, grants line P2 - Increasing economic competitiveness through RDI Romanian. (UEFISCDI, 2015) One of this grant line objectives was support smart specialization processes by concentrating resources in areas of economic relevance and potential research demonstrated through public-public and public-private. 
Furthermore, sustainability projects and their reporting have continuously evolved, as organizations attempted to respond to stakeholders' expectations for more transparency regarding how sustainability matters impact their strategy, operations and long-term prospects. Basing on this background, the expected positive influence of universities' engagement in sustainability issues on the IC disclosure index was also confirmed by our model, thus being in line with prior evidence stating that more socially responsible universities have a higher level of disclosure (Bisogno, Citro and Tommasetti, 2014).

These results create the premises for future involvement of universities and research institutes into the related bio-economics.

\section{Conclusions}

At EU level there is a huge interest on this topic, for this reason it was adopted a strategy for developing a sustainable bio-economy. In line with EU strategi, also Romania consider very important the domain, and a significant funding through national research organisms was assured. Recently, universities have launched new courses and master programs and conferences in bio-economy, created laboratories or research centers, innovation and technology transfer, participate in clusters which are a guarantee for cooperation with society's needs. So, in the university context the IC "is a term used to cover all the institution's non-tangible or non-physical assets, including processes, capacity for innovation, patents, the tacit knowledge of its members and their abilities, talents and skills, the recognition of society, its network of collaborators and contacts" (Ramirez, Tejada and Manzaneque, 2016).

In this context we agree that our study achieves an actual subject and his results are useful for scientific literature and practical bio-economy development. Our study through an original proposed IC disclosure framework achieves to cover an important gap for scientific literature, according to which there are insufficient instruments to manage and report the IC in universities (Sangiorgi and Siboni, 2017). The quantitative analysis based on the IC disclosure index and its determinants, underline the universities' role by IC as a mean for achieving a sustainable economy and promoting bio-economy as a component of the knowledge society.

The study and its results help to overcome the limit recognized by literature by which the private environment reveals more information of intellectual capital than the public sector, a possible explanation being the competitive environment (Low, Samkin and Li, 2015). An overwhelming influence is the entrepreneurial connotation of the public sphere (in this case the universities) which, according to the theory of interested parties, must increase the degree of accountability and transparency in order to ensure that society's current needs are met. Moreover, the quality of the information provided under the proposed CI publication framework succeeds in stimulating effective decisions, which the agency's insistence insists on.

The limits of this study concerns the sources of data regarding the universities IC, being collected only by consultation their websites, and by this maybe some elements not disclosed via websites were not considered. But, even with this limitation, this study should be a benchmark in appreciating each university's value and interest in the business environment and their ability to face new challenges. In particular, the empirical studies on IC- especially on its disclosure - are still limited and offer considerable room for future investigations. 
Moreover, the complexity and novelty of this bio-economy field require new research, new concepts, ideas and models, as well as further case studies for understanding economic, managerial and business facets of the phenomena, focusing on the universities' IC and knowledge management in the European environment. Starting from the results of the research, we believe that in the future studies one can more exploit the positive influence of the universities' involvement by the extent of CI's disclosure on stimulating research in the sphere of bioeconomy, with favorable effects on the whole society. In this context, decisionmakers could stimulate through differentiated funding, universities that produce knowledge and $\mathrm{CI}$ focused on bioeconomics, needed to sustain a sustainable bio-economy.

\section{References}

An, Y., Davey, H., and Eggleton, I., 2011. Towards a comprehensive theoretical framework for voluntary IC disclosure. Journal of Intellectual Capital, 12(4), pp. 571-585.

Banks, W., Fisher, J. and Nelson, M., 1997. University accountability in England, Wales, and Northern Ireland: 1992-1994. Journal of International Accounting, Auditing and Taxation, 6(2), pp. 211-226.

Bisogno, M., Citro, F. and Tommasetti, A., 2014. Disclosure of university websites. Evidence from Italian data. Global Business and Economics Review, 16(4), pp. 452-471.

Boubaker, S., Lakhal, F. and Nekhili, M., 2011. The determinants of web-based corporate reporting in France. Managerial Auditing Journal, 27(2), pp. 126-155.

Cuozzo, B., Dumay, J., Palmaccio, M. and Lombardi, R., 2017. ICdisclosure: a structured literature review. Journal of Intellectual Capital, 18(1), pp. 9-28.

Dabija, D.C., Postelnicu, C., Dinu, V., Mihăilă, A. 2017. Stakeholders' perception of sustainability orientation within a major Romanian University. International Journal of Sustainability in Higher Education, 18(4), pp. 533-553.

Danubius University, 2018. Presentation of the Master Program - Bioeconomic Management in the context of sustainable development at Danubius University Galati. [online] Available at: <http://www.univ-danubius.ro/facultatea-de-stiinte-economice-2/masterfacultatea-de-stiinte-economice/258-managementul-bioeconomiei-in-contextul-cresteriidurabile.html> [Accessed 4 February 2018].

Deaconu, A. and Nistor, C.S., 2015. Competences in Romanian higher education - an empirical investigation for the business sector. Studies in Higher Education, 42(11), pp. 1917-1940.

Donaldson, T. and Preston, L.E., 1995. The Stakeholder Theory of the Corporation: Concepts, Evidence, and Implications. The Academy of Management Review, 20(1), pp. 65-91.

Dragos, C.M., Dinu, V., Pop, C.M. and Dabija, D.C., 2014. Scientometric approach of productivity in scholarly economics and business. Economic Research-Ekonomska Istraživanja, 27(1), pp. 496-507.

Dumay, J., 2016. A critical reflection on the future of intellectual capital: from reporting to disclosure. Journal of Intellectual Capital, 17(1), pp. 168-184.

Dumay, J. and Cai, L., 2015. Using content analysis as a research methodology for investigating IC disclosure: a critique. Journal of Intellectual Capital, 16(1), pp. 121-155. 
Dumay, J. and Guthrie, J., 2017. Involuntary disclosure of intellectual capital: is it relevant? Journal of Intellectual Capital, 18(1), pp. 29-44.

Dumitru, V.F., Stanciu, A., Dumitru, M. and Feleagă, L., 2014. Pressure and isomorphism in business education. Amfiteatru Economic, 16(37), pp. 784-799.

EC, 2006. Encourage corporate measuring and reporting on research and other forms of IC. [online] Available at: <http://ec.europa.eu/invest-in-research/pdf/download_en/20062977_web1.pdf> [Accessed 12 January 2018].

EC, 2012. Innovating for Sustainable Growth. A bioeconomy for Europe. [online] Available at: 〈http://ec.europa.eu/research/bioeconomy/pdf/official-strategy_en.pdf> [Accessed 16 January 2018].

EC, 2010. The Knowledge Based Bio-Economy (KBBE) in Europe: Achievements and Challenges. [online] Available at: <http://www.mercadosbiotecnologicos.com/ documents/

the_knowledge_based_bioeconomy_kbbe_in_europe.pdf> [Accessed 12 February 2018].

Fazlagic, A., 2005. Measuring the IC of a university. In: OECD - Conference on the Trends in the Management of Human Resources in Higher Education. Paris, France, 25-26 August 2005. [online] Available at: <http://www.oecd.org/education/imhe/35322785.pdf> [Accessed 16 January 2018].

Gallego-Alvarez, I., Rodriguez-Dominguez, L. and Garcia-Sanchez, I.M., 2011. Information disclosed online by Spanish universities: content and explanatory factors. Online Information Review, 35(3), pp. 360-385.

Giampietro, M. and Passtore, G., 1999. Biophysical roots of 'enjoyment of life' according to Georgescu-Roegen's bioeconomic paradigm. In: K. Mayumi and J.M. Gowdy (eds.). Bioeconomics and sustainability. Cheltenham: Edward Elgar Publication. pp. 87-325.

Gordon, T.P. and Fischer, M., 2008. Communicating performance: the extent and effectiveness of performance reporting by US colleges and universities. Journal of Public Budgeting, Accounting and Financial Management, 20(2), pp. 217-255.

Hague, D. and Oakley, K., 2000. Spin-Offs and Start-Ups in UK universities. London: Committee of Vice-Chancellors and Principals (CVCP).

Ismail, S. and Bakar, N.B.A., 2011. Reporting practices of Malaysian public universities: The extent of accountability disclosure. African Journal of Business Management, 5(15), pp. 63-66.

Krauss, J. and Kuttenkeuler, D., 2018, Intellectual property rights derived from academic research and their role in the modern bioeconomy - A guide for scientists. New Biotechnology, 40(1), pp. 133-139.

Krippendorff, K., 2013. Content analysis: An introduction to its methodology. Beverly Hills: Sage Publications.

Lainez, M., Gonzalezb, J., Aguilarc, A. and Vela, C., 2018. Spanish strategy on bioeconomy: Towards a knowledge based sustainable. New Biotechnology, 40(1), pp. 87-95.

Leydesdorff, L. and Meyer, M., 2003. The triple helix of university-industry-government relations: Guest editorial. Scientometrics, 58(2), pp. 191-203.

Low, M., Samkin, G. and Li, Y., 2015. Voluntary reporting of intellectual capital: Comparing the quality of disclosures from New Zealand, Australian and United Kingdom universities. Journal of Intellectual Capital, 16(4), pp. 779-808. 
Manes Rossi, F. Citro, F. and Bisogno, M., 2016. IC in action: evidence from Italian local governments. Journal of Intellectual Capital, 17(4), pp. 696-713.

McCormick, K. and Kautto, N., 2013. The bioeconomy in Europe: an overview. Sustainability, 5(2), pp. 589-608.

Methora, V., Methora, A.K. and Chauhan, A.K, 2017. Determinants of IC disclosure - Indian companies, International Journal of Learning and Intellectual Capital, 14(4), pp. 366-387

Ministry of Research and Innovation, 2016. Presentation of Projects on Economic Development Priorities in Romania - Innovative Regional Groups of Bioeconomy in the Botosani-Suceava Area. [online] Available at: <http://www.poc.research.gov.ro/ ro/articol/4143/rezultate-proiecte-2007-2013> [Accessed 4 February 2018].

Oliveira, L., Rodrigues, L. and Craig, R., 2013. Stakeholder theory and the voluntary disclosure of IC information. Caspian Journal of Applied Sciences Research, 2(3), pp. 75-93.

Ramirez, Y., Tejada, A. and Manzaneque, M., 2016. The value of disclosing ICin Spanish universities: A new challenge of our days. Journal of Organizational Change Management, 29(2), pp. 176-198.

Romanian Government, 2011. Order no. 5262 for the acknowledgement of results for university classification. [online] Available at: <http://www.dreptonline.ro/legislatie/ordin_5262_2011_ constatarea> [Accessed 4 January 2018].

Romanian Government, 2014. National Strategy for Research, Development and Innovation 2014-2020. [online] Available at: <http://legislatie.just.ro/Public/DetaliiDocument/ 162510> [Accessed 4 February 2018].

Sanchez, M. and Elena, S., 2006. IC in universities: improving transparency and internal management. Journal of Intellectual Capital, 7(4), pp. 529-548.

Sanchez, M., Elena, S. and Castrillo, R., 2009. IC dynamics in universities: a reporting model. Journal of Intellectual Capital, 10(2), pp. 307-324.

Sangiorgi, D. and Siboni, B., 2017. The disclosure of IC in Italian universities: What has been done and what should be done. Journal of Intellectual Capital, 18(2), pp. 354-372.

Satler, A. and Martin, B., 2001. The economic benefits of publicly funded basic research. Research Policy, 30(3), pp. 509-532.

Schneider, A. and Samkin, G., 2008. IC reporting by the New Zealand local government sector. Journal of Intellectual Capital, 9(3), pp. 456-486.

Secundo, G., Beer, C. and Passiante, G., 2017. Mobilising IC to improve EU universities'competitiveness: the technology transfer offices' role. Journal of Intellectual Capital, 18(3), pp. 607-624.

Serrano-Cinca, C., Mar Molinero, C. and Bossi Queiroz, A., 2003. The measurement of intangible assets in public sector using scaling techniques. Journal of Intellectual Capital, 4(2), pp. 249-275.

Staffas, L., Gustavsson, M. and McCormick, K., 2013. Strategies and policies for the bioeconomy and bio-based economy: an analysis of official national approaches. Sustainability, 5(2), pp. 751-769.

UEFISCDI, 2015. Presentation of the National Financing Program through UEFISCDI, line P2 - Increasing economic competitiveness through Romanian RDI. [online] Available at: $\langle$ https://uefiscdi.ro/p2-cresterea-competitivitatii-economiei-romanesti-prin-cdi> [Accessed 4 February 2018]. 
Urdari, C., Farcas, T.V., Tiron-Tudor, A., 2017. Assessing the legitimacy of HEIs' contributions to society: The perspective of international rankings. Sustainability Accounting, Management and Policy Journal, 8(2), pp. 191-215.

van Weenen, H., 2000. Towards a vision of a sustainable university. International Journal of Sustainability in Higher Education, 1(1), pp. 20-34.

Yi, A. and Davey, H., 2010. IC disclosure in Chinese (mainland) companies. Journal of Intellectual capital, 11(3), pp. 326-347. 